\title{
Chemical Speciation of Some metal ions in Groundwaters of Yola Area Using Geochemical Model
}

\section{${ }^{1 *}$ GABRIEL IKE OBIEFUNA; ${ }^{2}$ DONATUS MADUKA ORAZULIKE}

\author{
${ }^{1}$ Department of Geology, Federal University of Technology, Yola, Nigeria \\ ${ }^{2}$ Geology Programme, Abubakar Tafawa Balewa University, Bauchi, Nigeria \\ Corresponding Author: *E-mail: gobiefuna2000@yahoo.com Mobile Phone: +2348034964345
}

\begin{abstract}
Chemical speciation of some metal ions in groundwaters of Yola area using geochemical model were carried out to determine the water quality of the area using the PHREEQC speciation model. The study findings based on model calculations indicated that free $\mathrm{Na}^{+}, \mathrm{Ca}^{2+}, \mathrm{Mg}^{2+}$ and $\mathrm{K}^{+}$ions are present and the consequent bioavailability are $95.83 \%$ to $99.84 \%$ at the $\mathrm{pH}$ ranges of 6.1 to 7.8 of the tested wells. Iron as free $\mathrm{Fe}^{2+}$ was bioavailable at $46.53 \%$ to $79.37 \%$ of the total iron. The lower values of free $\mathrm{Fe}^{2+}$ ions are related to the organic complexation of the ions. The model findings suggest that $\mathrm{Fe}^{2+}$ levels present a health risks in some water samples. The result also indicate that the concentration of $\mathrm{Na}^{+}, \mathrm{Ca}^{2+}, \mathrm{Mg}^{2+}$ and $\mathrm{K}^{+}$at such level would be available for uptake by plants, animals and humans. @ JASEM
\end{abstract}

Groundwater contains a wide variety of dissolved inorganic species in various concentrations, as a result of chemical and biochemical interactions between groundwater and the geological materials through which it flows, and to a lesser extent because of contributions from the atmosphere and surface water bodies (Freeze and Cherry, 1979). The presence of various inorganic constituents in groundwater is controlled by the reaction mechanisms such as dissolution/precipitation reactions and adsorption including the rates (kinetics) of the geochemical process (Appelo and Postma, 1993). Analytical techniques such as spectrometry and chromatography provide important information about the metals concentration in water, ions in groundwater can form unlimited number of species due to the hydrolysis, complexation and redox reactions (Baes and Mesmer., 1979). The selected five metals are of importance to water chemistry. Calcium is an essential alkaline-earth element for plant and animal life forms, and the solubility of its carbonate in water results in stalactites and stalagmites and hardness in water. Sodium is widely used in the manufacture of sodamide, sodium cyanide, sodium peroxide and sodium hydride as well as in the preparation of tetraethyl lead $\mathrm{PbEt}_{4}$ an important anti-knock agent in gasoline. Such applications tend to increase its level in the environment. Magnesium is produced from various activities especially in making organomagnesium compounds, useful in organic synthesis and is also an essential alkaline-earth element for plant and animal nutrition. Potassium is used in the manufacture of fertilizers usually as chlorides, sulphate, nitrate and carbonate and is extensively deposited in the environment. Iron is the cheapest and most abundant, useful (especially as an alloy in the production of steel) and important of all metals. Such qualities tend to increase its level in the environment. The PHREEQC speciation model was used to calculate ion activities. The PHREEQC model is a geochemical speciation model that is capable of computing specific equilibrium ion activities among the dissolved and adsorbed species and their equilibrium solid phase. The model is able to consider the interaction of major cations with anions $\left(\mathrm{Cl}^{-}, \mathrm{SO}_{4}{ }^{2-}\right.$, $\mathrm{HCO}_{3}{ }^{-}$and $\mathrm{CO}_{3}{ }^{2-}$ ) as a function of temperature, ionic strength and $\mathrm{pH}$. The aim of this study is to estimate the activities of various ionic species of sodium, calcium, magnesium, potassium and iron in groundwater using geochemical models from the measured ion concentrations.

The Study Area: The study area fall within longitudes $12^{\circ} 20^{\prime} \mathrm{E}$ and $12^{\circ} 34^{\prime} \mathrm{E}$ and latitudes $9^{\circ} 11^{\prime} \mathrm{N}$ and $9^{\circ} 24^{\prime} \mathrm{N}$ and lies about $50 \mathrm{~km}$ south of the Hawal Massifs. It is bounded to the east by the Republic of Cameroun and to the west by Ngurore town. The northern boundary is demarcated by Gokra town and the southern boundary by the Mandarare town and occupies approximately $431 \mathrm{~km}^{2}$ of the land surface.

\section{MATERIALS AND METHODS}

The investigation of groundwater chemistry in the study area started with the chemical analyses of ninety-six water samples collected from shallow hand-dug wells (80), deep wells (11), surface waters (11) and precipitation (5) in Yola Area; Figure 1. Samples collection was aimed at covering and representing the lateral and vertical extent of the hydrostratigraphic units within the study area along with surface water and rainfall.

The samples from the deep wells in which pumps are already installed, were collected after a few hours of pumping and the screen interval of the well represents the average sample depth. Samples from the shallow hand-dug wells were bailed, using a stainless steel bailer, from a depth of a few meters below the water table, which more or less indicates the sample depth (Abdalla, 2009). The samples were collected in 1000$\mathrm{ml}$ plastic bottles and field filtration was carried out through filter papers $(0.45 \mathrm{um})$ to remove suspended solids. They were then carefully sealed, labeled and taken for analyses. Chemical analyses were performed in the laboratory of the Adamawa State Water Board Yola, Nigeria employing standard methods, Atomic Absorption Spectrophotometry for cations $\left(\mathrm{Na}^{+}, \mathrm{Ca}^{2+}, \mathrm{Mg}^{2+}, \mathrm{K}^{+}, \mathrm{Fe}\right)$ and conventional 
titration for anions $\left(\mathrm{HCO}_{3}{ }^{-}, \mathrm{SO}_{4}{ }^{2-}, \mathrm{Cl}^{-}, \mathrm{NO}_{3}{ }^{-}\right)$. Ions were converted from milligram per litre to milliequivalent per litre and anions balanced against cations as a control check of the reliability of the analyses results.

Geochemical Modeling: The hydrogeochemical computer model PHREEQC (Parkhurst and Appelo 1999) performs speciation calculations based on the law of mass action which states that for a reaction of the generalized type:

$\mathrm{aA}+\mathrm{bB} \leftrightarrow \mathrm{cC}+\mathrm{dD}$

the distribution at equilibrium of the species at the left and right side of the reaction is given by: $\mathrm{K}=[\mathrm{C}]^{\mathrm{c}}[\mathrm{D}]^{\mathrm{d}} /[\mathrm{A}]^{\mathrm{a}}[\mathrm{B}]^{\mathrm{b}}$

where; $\mathrm{K}$ = equilibrium constant and the bracketed quantities denote activities or effective concentrations. In the present investigations we equate activities with molal concentrations.

PHREEQC (Parkhurst and Appelo 1999) is a computer model for performing hydrogeochemical calculations such as exchange and surface complexations, mineral reactions and equilibrations and mixing of water. PHREEQC operates with input files in which the calculation instructions are arranged according to key-words. These keywords are largely self-instructive as is illustrated by the example input file below where the keywords have been capitalized. Several databases are available with constants for the various reactions. The aqueous concentrations in a solution are defined with SOLUTION. The symbols for the elements are listed in the first column of SOLUTION_MASTER_SPECIES in the database. SOLUTION 1

Speciate and analyses, calculate saturation indices

Temp 25 \# temperature in degrees celcius, default = $25{ }^{\circ} \mathrm{C}$

$$
\begin{aligned}
& \text { pH } 7.0 \quad \# \text { default } \mathrm{pH}=7 \\
& \text { pe } 4.0 \# \text { pe }=-\log \text { (electron activity), default = } \\
& \begin{array}{l}
\text {-units } \mathrm{mmol} / \mathrm{kgw} \\
\mathrm{mmol} / \mathrm{kg} \text { water }
\end{array} \\
& \mathrm{Ca} 3.0 \quad \text { default units } \\
& \mathrm{Na} 1.0
\end{aligned}
$$

\section{K 2.0}

$\mathrm{Mg} 4.0$

Alkalinity 3.8 as $\mathrm{HCO}_{3}$ \# mmol charge / kgw

S $1.0 \#$ total sulphur, mainly sulphate, $\mathrm{S}(6)$, at pe = 4

$\mathrm{N}$ (5) \# nitrogen in the form of nitrate, $\mathrm{N}$ (5) $\mathrm{Cl}$ 1.0

Water $1 \quad$ \#g water default $=1 \mathrm{~kg}$

Density 1 \# density, default $=1 \mathrm{~kg} / \mathrm{L}$

END

PHREEQC has been enhanced with several new features to increase applicability, such as onedimensional transport with dispersion and diffusive exchange with stagnant zones, exchangers and surfaces that can be coupled to varying amounts of minerals or reactants, and generalized kinetics (Parkhurst and Appelo 1999). This version has been used to calculate the data shown in Tables 2, 3 and 4.

\section{RESULTS AND DISCUSSION}

Analytical data are provided in Table 1. The $\mathrm{pH}$ values for tested samples varied from 6.1 to 7.8 for shallow groundwater, 6.8 to 7.8 for deep groundwater and 7.20 to 8.00 in surface water samples. Sodium concentrations range was between 0 and $157 \mathrm{mg} / \mathrm{l}$ in shallow groundwater $0.00191 .00 \mathrm{mg} / \mathrm{l}$ in deep groundwater and 2.23 to $211 \mathrm{mg} / \mathrm{l}$ for the surface waters respectively. In shallow groundwater potassium concentration ranges from 0 to $37 \mathrm{mg} / \mathrm{l}, 0$ to $12.10 \mathrm{mg} / \mathrm{l}$ in deep groundwater and 1.20 to 9.00 $\mathrm{mg} / \mathrm{l}$ for the surface waters respectively. The concentration of calcium in shallow groundwater samples are less than $25 \mathrm{mg} / \mathrm{l}$, less than $39 \mathrm{mg} / \mathrm{l}$ in deep groundwater samples and between 1.20 to 9 $\mathrm{mg} / \mathrm{l}$ in the surface water samples respectively. Magnesium concentration in shallow groundwater is less than $51 \mathrm{mg} / \mathrm{l}$, less than $55 \mathrm{mg} / \mathrm{l}$ in deep groundwater and between 12 and $84 \mathrm{mg} / \mathrm{l}$ in the surface water samples respectively. Iron concentrations range was between 0.001 and 1.80 $\mathrm{mg} / \mathrm{l}$ in shallow groundwater, 0 and $0.32 \mathrm{mg} / \mathrm{l}$ in deep groundwater and 0 to 0.73 in the surface water samples respectively.

Table 1: Physicochemical parameters of Surfacewater and groundwater Samples (values in $\mathrm{mg} / \mathrm{l}$ unless otherwise stated)

\begin{tabular}{|l|l|l|l|}
\hline Parameter & Shallow Groundwater & Deep Groundwater & Surfacewater \\
\hline Temp $\left({ }^{\circ} \mathrm{C}\right)$ & $(30-31) 30 \pm 0.06$ & $(30-32) 30.20 \pm 0.60$ & $(26-34) 29.56 \pm 3.02$ \\
\hline $\mathrm{pH}$ & $(6.10-7.08) 7.09 \pm 0.39$ & $(6.60-7.80) 7.22 \pm 0.41$ & $(7.20-8.00) 7.57 \pm 0.23$ \\
\hline $\mathrm{EC}(\mathrm{ds} / \mathrm{m})$ & $(0.05-0.21) 0.09 \pm 0.03$ & $(0.04-0.18) 0.09 \pm 0.04$ & $(0.07-0.45) 0.22 \pm 0.11$ \\
\hline $\mathrm{TDS}$ & $(33-137) 60 \pm 18.83$ & $(27-121) 63 \pm 26$ & $(41-298) 155 \pm 72.60$ \\
\hline $\mathrm{Na}^{+}$ & $(0-157) 34 \pm 33.74$ & $(0-91) 34 \pm 34.30$ & $(2.23-211) 73 \pm 89.04$ \\
\hline $\mathrm{K}^{+}$ & $(0-37) 4 \pm 6.89$ & $(0-12) 4.32 \pm 4.16$ & $(1.20-9.00) 5 \pm 2.40$ \\
\hline $\mathrm{Mg}^{2+}$ & $(0.50-51) 21 \pm 9.00$ & $(8-55) 31 \pm 13.46$ & $(12-84) 35 \pm 19.09$ \\
\hline $\mathrm{Ca}^{2+}$ & $(0.48-25) 12 \pm 6.19$ & $(0.50-38) 11.30 \pm 11.70$ & $(8-37) 26 \pm 9.25$ \\
\hline $\mathrm{Fe}$ & $(0-1.80) 0.35 \pm 0.41$ & $(0-0.32) 0.09 \pm 0.10$ & $(0.0 .73) 0.30 \pm 0.26$ \\
\hline $\mathrm{Fe}{ }^{2+}$ & $(0-0.70) 0.12 \pm 0.16$ & $(0-0.11) 0.03 \pm 0.04$ & $(0-0.40) 0.17 \pm 0.15$ \\
\hline $\mathrm{Fe}^{3+}$ & $(0-1.14) 0.22 \pm 0.27$ & $(0.21) 0.06 \pm 0.05$ & $(0-0.44) 0.14 \pm 0.13$ \\
\hline $\mathrm{NO}_{3}{ }^{-}$ & $(0-23) 4.36 \pm 4.63$ & $(0.66-31) 6 \pm 8.63$ & $(9-59) 35 \pm 17.97$ \\
\hline $\mathrm{Cl}^{-}$ & $(0-239) 68 \pm 56$ & $(0-172) 76 \pm 61.82$ & $(28-455) 146 \pm 138.28$ \\
\hline $\mathrm{HCO}_{3}{ }^{-}$ & $(19.90-251) 93.4 \pm 41$ & $(50-207) 103 \pm 44.4$ & $(49-273) 137 \pm 63.27$ \\
\hline $\mathrm{SO}_{4}{ }^{-}$ & $(0-61) 11 \pm 12.28$ & $(0-65) 14.80 \pm 19.66$ & $(2-29) 18 \pm 7.52$ \\
\hline
\end{tabular}


Table 2: Result of PHREEQC output file containing activities and concentrations of some ionic species in Shallow Groundwater samples (After Obiefuna in Preparation)

\begin{tabular}{|c|c|c|c|c|c|}
\hline Species & $\begin{array}{c}\text { Concentration } \\
\mathrm{mg} / \mathrm{l}\end{array}$ & Activity mg/l & Species & $\begin{array}{c}\text { Concentration } \\
\mathrm{mg} / \mathrm{l}\end{array}$ & Activity \\
\hline $\mathrm{Ca}^{2}+$ & $2.923 \mathrm{E}-004$ & $2.145 \mathrm{E}-004$ & $\mathrm{Na}+$ & $1.492 \mathrm{E}-003$ & $1.380 \mathrm{E}-003$ \\
\hline $\mathrm{CaHCO}_{3}+$ & $6.089 \mathrm{E}-006$ & $5.636 \mathrm{E}-006$ & $\mathrm{NaHCO}_{3}(\mathrm{aq})$ & $1.490 \mathrm{E}-006$ & $1.492 \mathrm{E}-006$ \\
\hline $\mathrm{CaSO}_{4}$ & $3.161 \mathrm{E}-006$ & $3.165 \mathrm{E}-006$ & $\mathrm{NaHPO}_{4}$ & $4.535 \mathrm{E}-008$ & $4.189 \mathrm{E}-008$ \\
\hline $\mathrm{CaHPO}_{4}$ & 2.005E-006 & $2.008 \mathrm{E}-006$ & $\mathrm{NaSO}_{4-}$ & $5.455 \mathrm{E}-007$ & $5.039 \mathrm{E}-007$ \\
\hline $\mathrm{CaCO}_{3}(\mathrm{aq})$ & $4.892 \mathrm{E}-007$ & $4.898 \mathrm{E}-07$ & $\mathrm{NaCO}_{3^{-}}(\mathrm{aq})$ & $4.346 \mathrm{E}-008$ & $4.014 \mathrm{E}-008$ \\
\hline CaH2PO4+ & $1.295 \mathrm{E}-007$ & $1.197 \mathrm{E}-07$ & $\mathrm{NaF}$ & $1.472 \mathrm{E}-009$ & $1.474 \mathrm{E}-009$ \\
\hline $\mathrm{CaPO}_{4^{-}}$ & $6.941 \mathrm{E}-008$ & $6.411 \mathrm{E}-008$ & $\mathrm{NaOH}$ & $1.120 \mathrm{E}-010$ & $1.121 \mathrm{E}-010$ \\
\hline $\mathrm{CaF}+$ & $4.212 \mathrm{E}-009$ & $3.890 \mathrm{E}-009$ & $\mathrm{Fe}+2$ & $2.292 \mathrm{E}-006$ & $1.690 \mathrm{E}-006$ \\
\hline $\mathrm{CaOH}+$ & $4.741 \mathrm{E}-010$ & $4.379 \mathrm{E}-010$ & $\mathrm{FeHCO}_{3}+$ & $3.518 \mathrm{E}-007$ & $3.250 \mathrm{E}-007$ \\
\hline CaHSO4+ & $1.742 \mathrm{E}-012$ & 1.609E-012 & $\mathrm{FeHPO}_{4}$ & $1.046 \mathrm{E}-007$ & $1.048 \mathrm{E}-007$ \\
\hline $\mathrm{K}+$ & $1.010 \mathrm{E}-004$ & $9.320 \mathrm{E}-005$ & $\mathrm{FeCO}_{3}$ & $4.937 \mathrm{E}-008$ & $4.943 \mathrm{E}-008$ \\
\hline $\mathrm{KSO}_{4^{-}}$ & $5.456 \mathrm{E}-008$ & $5.040 \mathrm{E}-008$ & $\mathrm{Fe}(\mathrm{HS}) 2$ & $3.371 \mathrm{E}-008$ & $3.375 \mathrm{E}-008$ \\
\hline $\mathrm{KHPO}_{4-}$ & 3.064E-009 & $2.830 \mathrm{E}-009$ & FeSO4 & 2.319E-008 & $2.322 \mathrm{E}-008$ \\
\hline $\mathrm{KOH}(\mathrm{aq})$ & $3.970 \mathrm{E}-012$ & $3.975 \mathrm{E}-012$ & FeH2PO4+ & $1.818 \mathrm{E}-008$ & $1.608 \mathrm{E}-008$ \\
\hline $\mathrm{Mg}^{2+}$ & $8.201 \mathrm{E}-004$ & $6.041 \mathrm{E}-004$ & $\mathrm{FeOH}+$ & $1.028 \mathrm{E}-008$ & $9.492 \mathrm{E}-009$ \\
\hline $\mathrm{MgHCO}_{3}+$ & $1.509 \mathrm{E}-005$ & $1.394 \mathrm{E}-005$ & $\mathrm{FeCl}+$ & $4.483 \mathrm{E}-009$ & $4.141 \mathrm{E}-009$ \\
\hline $\mathrm{MgSO} 4$ & $1.134 \mathrm{E}-005$ & $1.135 \mathrm{E}-005$ & $\mathrm{FeF}+$ & $3.397 \mathrm{E}-011$ & $3.137 \mathrm{E}-011$ \\
\hline MgHPO4 & $7.636 \mathrm{E}-006$ & $7.645 \mathrm{E}-006$ & $\mathrm{Fe}(\mathrm{HS})_{3}$ & $1.884 \mathrm{E}-011$ & $1.704 \mathrm{E}-011$ \\
\hline $\mathrm{MgCO}_{3}$ & 7.581E-007 & 7.591E-007 & $\mathrm{FeHSO}_{4}+$ & $1.372 \mathrm{E}-014$ & $1.268 \mathrm{E}-014$ \\
\hline $\mathrm{MgH}_{2} \mathrm{PO}_{4}+$ & $4.646 \mathrm{E}-007$ & $4.292 \mathrm{E}-007$ & $\mathrm{Fe}(\mathrm{OH})_{3}+$ & $2.158 \mathrm{E}-006$ & $2.160 \mathrm{E}-006$ \\
\hline $\begin{array}{l}\text { MgPO4- } \\
\text { (aq) }\end{array}$ & $2.637 \mathrm{E}-007$ & $2.436 \mathrm{E}-007$ & $\mathrm{Fe}(\mathrm{OH})_{2}+$ & 1.191E-006 & $1.100 \mathrm{E}-006$ \\
\hline $\mathrm{MgF}+$ & $8.771 \mathrm{E}-008$ & $8.102 \mathrm{E}-008$ & $\mathrm{Fe}(\mathrm{OH})_{4-}$ & $3.197 \mathrm{E}-008$ & 2.953E- 008 \\
\hline $\mathrm{MgOH}+$ & $4.554 \mathrm{E}-008$ & $4.207 \mathrm{E}-008$ & $\mathrm{FeOH}+2$ & $3.079 \mathrm{E}-010$ & $2.241 \mathrm{E}-010$ \\
\hline
\end{tabular}

Tabulated analytical values of major cations, anions, and $\mathrm{pH}$ were used to create the input data file (Obiefuna in Preparation). Generated output by the model included the calculated ionic strength in the analyzed samples and activities of various metal ionic species whether free or complexed ions. A variety of reactions may occur which influences the speciation and mobility of metal contaminants including acid/base, precipitation/dissolution, sorption and ion exchange reactions can retard the movement of metals in groundwater. The rate and extent of these reactions will depend on factors such as $\mathrm{pH}$, Eh, complexation with other dissolved constituents, sorption and ion exchange capacity of the geological materials and organic matter content. Groundwater flow characteristics also influence the transport of metal contaminants. Chemical Speciation of Sodium: In natural water system dissolved sodium occurs in +1 oxidation state. The results indicate that $\mathrm{Na}^{+}$is the most soluble chemical species of sodium in shallow groundwater and represent about $99 \%$ of the sodium. Complexed species indicate that $0.09 \%$ occurs as bicarbonate, $0.03 \%$ as sulphates and less than $0.002 \%$ as other anions.In deep groundwater $\mathrm{Na}^{+}$represent $99.84 \%$ of the sodium whereas complexed species revealed that $0.10 \%$ occur as bicarbonates, $0.05 \%$ as sulphate and $0.004 \%$ as carbonate respectively. In surface water $\mathrm{Na}^{+}$represent $99.82 \%$ of the sodium while complexed species disclosed that $0.12 \%$ occur as bicarbonate, $0.04 \%$ as sulphate, $0.02 \%$ as $\mathrm{NaHPO}_{4}$ and $0.01 \%$ as $\mathrm{NaCO}_{3}$. Sodium can be removed from natural water by ion exchange and sorption to mineral surfaces.Removal by these mechanisms increases as $\mathrm{pH}$ increases. Sorption is also influenced by the cation exchange capacity (CEC) of clays, carbonate minerals and organic matter present in soils and sediments. Ion exchange and sorption of $\mathrm{Na}^{+}$controls the mobility of sodium. In surface water and groundwater systems, a significant fraction of sodium is undissolved and occurs as precipitates $\left(\mathrm{NaHCO}_{3}\right.$, $\mathrm{Na}_{2} \mathrm{SO}_{4}$ ), sorbed ions or surface coatings on minerals, or as suspended organic matter.

Chemical Speciation of Potassium: Potassium like sodium has only one significant oxidation state $\mathrm{K}^{+}$ and it tends to be soluble in most types of natural water as sodium. Chemical speciation of Potassium in shallow groundwater with different anions is shown in Figure 5. It indicate that $99.94 \%$ of potassium exists as free $\left(\mathrm{K}^{+}\right)$, about $0.05 \%$ as sulphate, $0.003 \%$ as $\mathrm{KHPO}_{4}$ and about $0.0005 \%$ as $\mathrm{KOH}$. In deep groundwater the chemical speciation of potassium with different anions indicate that $99.93 \%$ of potassium exists as free ions $\left(\mathrm{K}^{+}\right), 0.07 \%$ as sulphate, $0.003 \%$ as $\mathrm{KHPO}_{4}$ and $0 \%$ as $\mathrm{KOH}$ respectively. In surface water samples an estimated $99.93 \%$ of potassium occurs in free ionic form $\left(\mathrm{K}^{+}\right), 0.06 \%$ occurs as $\mathrm{KSO}_{4}, 0.02 \%$ as $\mathrm{KHPO}_{4}$ and $0 \%$ as $\mathrm{KOH}$ respectively. 
Table 3 Summary of PHREEQC output file containing activities and concentrations of some ionic species in Deep Groundwater Samples (After Obiefuna in Preparation)

\begin{tabular}{|c|c|c|c|c|c|}
\hline Species & $\begin{array}{c}\text { Concentration } \\
\mathrm{mg} / \mathrm{l}\end{array}$ & Activity $\mathrm{mg} / \mathrm{l}$ & Species & $\begin{array}{c}\text { Concentration } \\
\mathrm{mg} / \mathrm{l}\end{array}$ & Activity \\
\hline $\mathrm{Ca}^{2}+$ & $2.700 \mathrm{E}-004$ & $1.934 \mathrm{E}-004$ & $\mathrm{NaHCO}_{3}(\mathrm{aq})$ & $1.528 \mathrm{E}-006$ & $1.530 \mathrm{E}-006$ \\
\hline $\mathrm{CaHCO}_{3}+$ & $5.823 \mathrm{E}-006$ & s.358E-006 & $\mathrm{NaSO}_{4-}$ & $6.953 \mathrm{E}-007$ & $6.381 \mathrm{E}-007$ \\
\hline $\mathrm{CaSO} 4$ & $3.704 \mathrm{E}-006$ & 3.709E-006 & $\mathrm{NaCO}_{3^{-}}(\mathrm{aq})$ & $6.124 \mathrm{E}-008$ & $5.620 \mathrm{E}-008$ \\
\hline CaHPO4 & $1.720 \mathrm{E}-006$ & $1.722 \mathrm{E}-006$ & NaHPO4- & $4.220 \mathrm{E}-008$ & 3.873E-008 \\
\hline $\mathrm{CaCO} 3(\mathrm{aq})$ & $6.304 \mathrm{E}-007$ & $6.313 \mathrm{E}-007$ & $\mathrm{NaF}$ & $1.050 \mathrm{E}-009$ & $1.051 \mathrm{E}-009$ \\
\hline $\mathrm{CaH}_{2} \mathrm{PO} 4+$ & $8.284 \mathrm{E}-008$ & $7.602 \mathrm{E}-008$ & $\mathrm{NaOH}$ & $1.472 \mathrm{E}-010$ & $1.474 \mathrm{E}-010$ \\
\hline $\mathrm{CaPO}_{4^{-}}$ & $8.110 \mathrm{E}-008$ & 7.443E-008 & $\mathrm{Fe}+2$ & $2.939 \mathrm{E}-007$ & $2.116 \mathrm{E}-007$ \\
\hline $\mathrm{CaF}+$ & $2.807 \mathrm{E}-009$ & $2.576 \mathrm{E}-009$ & $\mathrm{Fe}(\mathrm{HS}) 2$ & $2.609 \mathrm{E}-007$ & $2.613 \mathrm{E}-007$ \\
\hline $\mathrm{CaOH}+$ & $5.802 \mathrm{E}-010$ & $5.325 \mathrm{E}-010$ & FeHCO3+ & $4.666 \mathrm{E}-008$ & 4.282E-008 \\
\hline $\mathrm{CaHSO}_{4}+$ & $1.527 \mathrm{E}-012$ & $1.401 \mathrm{E}-012$ & FeHPO4 & $1.243 \mathrm{E}-008$ & $1.244 \mathrm{E}-008$ \\
\hline $\mathrm{K}+$ & 1.104E-004 & $1.012 \mathrm{E}-004$ & $\mathrm{FeCO} 3$ & $8.800 \mathrm{E}-009$ & $8.813 \mathrm{E}-009$ \\
\hline $\mathrm{KSO}_{4^{-}}$ & $7.766 \mathrm{E}-008$ & $7.127 \mathrm{E}-008$ & FeSO4 & $3.781 \mathrm{E} 009$ & $3.786 \mathrm{E}-009$ \\
\hline $\mathrm{KHPO}_{4^{-}}$ & $3.177 \mathrm{E}-009$ & $2.916 \mathrm{E}-009$ & $\mathrm{FeOH}+$ & $1.770 \mathrm{E}-009$ & $1.624 \mathrm{E}-009$ \\
\hline $\mathrm{KOH}(\mathrm{aq})$ & $5.816 \mathrm{E}-012$ & $5.825 \mathrm{E}-012$ & $\mathrm{FeH} 2 \mathrm{PO}_{4}+$ & $1.610 \mathrm{E}-009$ & $1.478 \mathrm{E}-009$ \\
\hline $\mathrm{Mg}^{2+}$ & $1.212 \mathrm{E}-003$ & 8.719E-004 & $\mathrm{Fe}(\mathrm{HS})_{3^{-}}$ & $1.154 \mathrm{E}-009$ & 1.059E-009 \\
\hline $\mathrm{MgHCO}_{3}+$ & $2.308 \mathrm{E}-005$ & $2.118 \mathrm{E}-005$ & $\mathrm{FeCl}+$ & $6.222 \mathrm{E}-010$ & $1.5710 \mathrm{E}-010$ \\
\hline MgSO4 & $2.133 \mathrm{E}-005$ & $2.136 \mathrm{E}-005$ & $\mathrm{FeF}+$ & 3.132E-012 & $2.874 \mathrm{E}-012$ \\
\hline MgHPO4 & $1.049 \mathrm{E}-005$ & $1.050 \mathrm{E}-005$ & FeHSO4+ & $1.671 \mathrm{E}-015$ & $1.533 \mathrm{E}-015$ \\
\hline $\mathrm{MgCO} 3$ & $1.562 \mathrm{E}-006$ & $1.564 \mathrm{E}-006$ & $\mathrm{Fe}(\mathrm{OH}) 3$ & $6.859 \mathrm{E}-007$ & $6.870 \mathrm{E}-007$ \\
\hline $\mathrm{MgPO}_{4^{-}}(\mathrm{aq})$ & 4.934E-007 & $4.528 \mathrm{E}-007$ & $\mathrm{Fe}(\mathrm{OH}) 2+$ & $2.805 \mathrm{E}-007$ & $2.574 \mathrm{E}-007$ \\
\hline $\mathrm{MgH}_{2} \mathrm{PO}_{4}+$ & $4.757 \mathrm{E}-007$ & $4.366 \mathrm{E}-007$ & $\mathrm{Fe}(\mathrm{OH}) 4-$ & $1.390 \mathrm{E}-008$ & $1.276 \mathrm{E}-008$ \\
\hline $\mathrm{MgF}+$ & $9.350 \mathrm{E}-008$ & $8.581 \mathrm{E}-008$ & $\mathrm{FeOH}+2$ & $5.444 \mathrm{E}-010$ & $3.862 \mathrm{E}-011$ \\
\hline $\mathrm{MgOH}+$ & $9.065 \mathrm{E}-008$ & $8.319 \mathrm{E}-008$ & $\mathrm{FeH}_{2} \mathrm{PO} 4+2$ & $1.412 \mathrm{E}-015$ & $1.002 \mathrm{E}-015$ \\
\hline $\mathrm{Na}+$ & $1.464 \mathrm{E}-003$ & $1.345 \mathrm{E}-003$ & $\mathrm{Fe}+3$ & $5.336 \mathrm{E}-16$ & $2.671 \mathrm{E}-016$ \\
\hline
\end{tabular}

Chemical Speciation of Magnesium: In natural water system dissolved magnesium occurs in +2 oxidation state. Chemical speciation of magnesium in shallow groundwater samples indicate that $95.83 \%$ of magnesium is in the free ionic form $\left(\mathrm{Mg}^{2+}\right), 1.76 \%$ occurs as bicarbonate, $1.33 \%$ as sulphate, $0.89 \%$ as $\mathrm{MgHPO}_{4}$ and $0.09 \%$ as carbonate (Figure 8). The deep groundwater disclosed that $96.27 \%$ of magnesium exists as free ions $\left(\mathrm{Mg}^{2+}\right), 1.83 \%$ as bicarbonate, $1.69 \%$ as sulphate, $0.12 \%$ as carbonate and $0.04 \%$ as phosphates. The surface water samples revealed similar trends as $92.45 \%$ of magnesium occur in free ionic state, $3.94 \%$ as phosphates, $1.83 \%$ as bicarbonates, $1.21 \%$ as sulphate and $0.19 \%$ as carbonates. Under most conditions $\mathrm{Mg}^{2+}$ and magnesium-hydroxide complexes are the most stable forms of lead. Low solubility compounds are formed by complexation with inorganic $\mathrm{Cl}^{-}, \mathrm{CO}_{3}, \mathrm{SO}_{4}, \mathrm{PO}_{4}$. In surface water and groundwater systems, a significant fraction of magnesium is undissolved and occurs as precipitates $\left(\mathrm{MgPO}_{4}, \mathrm{MgCO}_{3}, \mathrm{MgSO}_{4}\right)$, sorbed ions or surface coatings on minerals, or suspended organic matter.

Chemical Speciation of Calcium: Calcium like magnesium has only one oxidation state $\mathrm{Ca}^{2+}$ and is largely soluble in most types of natural waters. Chemical speciation of calcium with different anions in shallow groundwater show that $96.07 \%$ exists as free ions $\left(\mathrm{Ca}^{2+}\right), 2 \%$ as bicarbonates, $1.04 \%$ as sulphates and $0.66 \%$ as phosphates. In deep groundwater samples $95.79 \%$ of calcium occurs as free ion $\left(\mathrm{Ca}^{2+}\right), 2.07 \%$ as bicarbonates, $1.31 \%$ as sulphates and less than $0.90 \%$ as phosphates and carbonates respectively. The surface water samples revealed values of $93.48 \%$ of calcium occurring in free ionic form $\left(\mathrm{Ca}^{2+}\right)$, and less than $7 \%$ occurring as phosphates, bicarbonates and sulphates respectively. Calcium can also be removed from natural water by ion exchange and sorption to mineral surfaces. Removal by these mechanisms increases as $\mathrm{pH}$ increases. Sorption is also influenced by the cation exchange capacity (CEC) of clays, carbonate minerals and organic matter present in soils and sediments. Ion exchange and sorption of $\mathrm{Ca}^{2+}$ controls the mobility of calcium. In surface water and groundwater systems, a significant fraction of sodium is undissolved and occurs as precipitates $\left(\mathrm{CaCO}_{3}\right.$, $\mathrm{CaSO}_{4}$ ), sorbed ions or surface coatings on minerals, or as suspended organic matter.

Chemical Speciation of Iron: Iron may occur in solution as $\mathrm{Fe}^{+2}$ or $\mathrm{Fe}^{+3}$ oxidation state. The redox conditions in oxygenated waters favour the more oxidized form $\left(\mathrm{Fe}^{3+}\right)$. Ferrous ions $\left(\mathrm{Fe}^{2+}\right)$ form complexes with a number of ligands, a strong $\mathrm{FeHCO}_{3}$ and $\mathrm{FeCO}_{3}$ appears likely to be the major form in natural water containing dissolved $\mathrm{CO}_{2}$. Chemical speciation of iron in shallow groundwater samples indicated that $79.37 \%$ of iron is in the free ionic form $\left(\mathrm{Fe}^{+2}\right), 12.18 \%$ as bicarbonate and less than $8 \%$ as phosphates, carbonates, sulphides and sulphates respectively. In deep groundwater $46.53 \%$ exists as free $\mathrm{Fe}^{2+}$ ions, $41.31 \%$ as sulphides, $7.39 \%$ 
as bicarbonates and less than $4 \%$ as phosphates, carbonates and sulphates. In surface water samples an estimated $22.58 \%$ of iron occurs in free ionic form $\left(\mathrm{Fe}^{2+}\right)$, a predominant $67 \%$ occur as sulphides while the remaining $10.42 \%$ occur as phosphates, bicarbonates and carbonates respectively. Iron is an extremely mobile ion and its removal from groundwater is in most cases an extremely difficult tasks. Under mild oxidizing conditions iron is in a +3 valence state and forms an insoluble precipitates, $\mathrm{Fe}_{2} \mathrm{O}_{3}$ while under reducing conditions is converted to +2 valence states and is present as soluble $\mathrm{Fe}^{2+}$ cation. Increased iron concentrations in water samples are due to re-dissolution of previously formed unstable precipitates or due to leaching of iron from the adjacent rocks that bounds the aquifers of the study area.

Table 4: Summary of PHREEQC output file containing activities and concentrations of some ionic species in surface water (After Obiefuna in Preparation)

\begin{tabular}{|c|c|c|c|c|c|}
\hline Species & $\begin{array}{c}\text { Concentration } \\
\mathrm{mg} / \mathrm{l}\end{array}$ & Activity mg/l & Species & $\begin{array}{c}\text { Concentration } \\
\mathrm{mg} / \mathrm{l}\end{array}$ & Activity \\
\hline $\mathrm{Ca}^{2}+$ & $5.995 \mathrm{E}-004$ & $3.909 \mathrm{E}-04$ & $\mathrm{MgF}+$ & $1.806 \mathrm{E}-007$ & 1.619E-007 \\
\hline CaHPO4 & $2.648 \mathrm{E}-005$ & $2.655 \mathrm{E}-005$ & $\mathrm{Na}+$ & $3.247 \mathrm{E}-003$ & $2.916 \mathrm{E}-003$ \\
\hline CaHCO3+ & $1.747 \mathrm{E}-005$ & $1.573 \mathrm{E}-006$ & $\begin{array}{l}\mathrm{NaHCO}_{3} \\
(\mathrm{aq})\end{array}$ & $4.844 \mathrm{E}-006$ & $4.856 \mathrm{E}-006$ \\
\hline $\mathrm{CaSO} 4$ & $8.112 \mathrm{E}-006$ & $8.132 \mathrm{E}-006$ & $\mathrm{NaSO}_{4-}$ & $1.677 \mathrm{E}-006$ & $1.504 \mathrm{E}-006$ \\
\hline $\begin{array}{l}\mathrm{CaCO} 3 \\
(\mathrm{aq})\end{array}$ & $4.067 \mathrm{E}-006$ & $4.077 \mathrm{E}-006$ & $\mathrm{NaHPO}_{4}$ & $7.221 \mathrm{E}-007$ & $6.476 \mathrm{E}-007$ \\
\hline $\mathrm{CaH} 2 \mathrm{PO} 4+$ & $5.854 \mathrm{E}-007$ & $5.250 \mathrm{E}-007$ & $\mathrm{NaCO}_{3}-(\mathrm{aq})$ & $4.273 \mathrm{E}-007$ & $3.832 \mathrm{E}-007$ \\
\hline $\mathrm{CaPO} 4$ & $2.832 \mathrm{E}-006$ & $2.540 \mathrm{E}-007$ & $\mathrm{NaOH}$ & $7.138 \mathrm{E}-010$ & $7.156 \mathrm{E}-010$ \\
\hline $\mathrm{CaOH}+$ & $2.687 \mathrm{E}-009$ & $2.409 \mathrm{E}-010$ & $\mathrm{NaF}$ & $4.438 \mathrm{E}-009$ & 4.449E-009 \\
\hline $\mathrm{CaF}+$ & $1.118 \mathrm{E}-008$ & $1.002 \mathrm{E}-010$ & $\mathrm{Fe}(\mathrm{HS})_{2}$ & $1.562 \mathrm{E}-010$ & $1.567 \mathrm{E}-010$ \\
\hline CaHSO4+ & $1.517 \mathrm{E}-012$ & $1.361 \mathrm{E}-012$ & $\mathrm{Fe}+2$ & 1.912E-007 & $1.265 \mathrm{E}-007$ \\
\hline $\mathrm{K}+$ & $1.332 \mathrm{E}-004$ & $1.192 \mathrm{E}-005$ & $\mathrm{FeHPO}_{4}$ & 5.723E-008 & 5.738E-008 \\
\hline $\mathrm{KSO}_{4^{-}}$ & $1.010 \mathrm{E}-007$ & $9.058 \mathrm{E}-008$ & $\mathrm{FeHCO}_{3}+$ & $4.179 \mathrm{E}-008$ & 3.748E-008 \\
\hline $\mathrm{KHPO}_{4^{-}}$ & $2.952 \mathrm{E}-008$ & $2.647 \mathrm{E}-008$ & $\mathrm{FeCO} 3$ & $1.704 \mathrm{E}-008$ & $1.708 \mathrm{E}-008$ \\
\hline $\mathrm{KOH}(\mathrm{aq})$ & $1.531 \mathrm{E}-011$ & $1.535 \mathrm{E}-012$ & FeH2PO4+ & $3.405 \mathrm{E}-009$ & $3.054 \mathrm{E}-009$ \\
\hline $\mathrm{Mg}+2$ & $1.289 \mathrm{E}-003$ & $8.522 \mathrm{E}-004$ & $\mathrm{Fe}(\mathrm{HS})_{3^{-}}$ & $2.242 \mathrm{E}-014$ & $2.010 \mathrm{E}-014$ \\
\hline $\mathrm{MgHPO}_{4}$ & $7.805 \mathrm{E}-005$ & $7.825 \mathrm{E}-005$ & $\mathrm{FeSO}_{4}$ & $2.436 \mathrm{E}-009$ & $2.443 \mathrm{E}-009$ \\
\hline $\mathrm{MgHCO}_{3}+$ & $3.367 \mathrm{E}-005$ & $3.020 \mathrm{E}-005$ & $\mathrm{FeCl}+$ & 7.177E-010 & $6.436 \mathrm{E}-010$ \\
\hline $\mathrm{MgSO} 4$ & $2.237 \mathrm{E}-005$ & $2.242 \mathrm{E}-005$ & $\mathrm{FeOH}+$ & $2.318 \mathrm{E}-009$ & $2.079 \mathrm{E}-009$ \\
\hline $\mathrm{MgH}_{2} \mathrm{PO} 4+$ & $1.625 \mathrm{E}-006$ & $1.458 \mathrm{E}-006$ & $\mathrm{FeF}+$ & $3.741 \mathrm{E}-012$ & $3.355 \mathrm{E}-012$ \\
\hline $\begin{array}{l}\mathrm{MgPO} 4- \\
(\mathrm{aq})\end{array}$ & $8.328 \mathrm{E}-006$ & 7.469E-006 & FeHSO4+ & $4.912 \mathrm{E}-016$ & $4.405 \mathrm{E}-016$ \\
\hline $\mathrm{MgCO} 3$ & $4.895 \mathrm{E}-006$ & $4.907 \mathrm{E}-006$ & $\mathrm{Fe}(\mathrm{OH}) 3$ & $4.088 \mathrm{E}-006$ & 4.098E-006 \\
\hline $\mathrm{MgOH}+$ & $1.922 \mathrm{E}-007$ & $1.724 \mathrm{E}-007$ & $\begin{array}{l}\mathrm{Fe}(\mathrm{OH})_{2}+ \\
\mathrm{Fe}(\mathrm{OH})_{4}\end{array}$ & $\begin{array}{l}7.852 \mathrm{E}-007 \\
1.854 \mathrm{E}-007\end{array}$ & $\begin{array}{l}7.042 \mathrm{E}-007 \\
1.663 \mathrm{E}-007\end{array}$ \\
\hline
\end{tabular}

Main iron precipitates are hematite $(\alpha \mathrm{FeO} 3)$ goethite $(\alpha-\mathrm{FeOOH})$ and to a lesser amounts ferrihydrite $\left(\mathrm{Fe}_{5} \mathrm{HO}_{8} \cdot 4 \mathrm{H}_{2} \mathrm{O}\right)$ or iron hydroxide $\left[\mathrm{Fe}(\mathrm{OH})_{3}\right]$. Geochemical speciation calculations suggest that at $\mathrm{pH}$ values between 5 and 6 copper precipitates as cupric and cuprous ferrite.

Iron precipitates can be quite massive and often cause serious clogging problems of drinking water wells.

Conclusions: The study findings based on model calculations indicated that $\mathrm{Na}^{+}, \mathrm{Ca}^{2+}, \mathrm{Mg}^{2+}$ and $\mathrm{K}^{+}$are highly soluble and consequently will be bioavailable at the $\mathrm{pH}$ ranges of the tested wells. Iron is also expected to be bioavailable as $46.53 \%$ to $79.37 \%$ of the total iron is presented as $\mathrm{Fe}^{2+}$. The lower values of $\mathrm{Fe}^{2+}$ are related to the organic complexation of the ions. Identifying ionic distributions is of particular importance as pollutants affect the groundwater environment by the chemical behavior of the ionic species and transformation of species than by total concentrations. The adverse effects of highly soluble free $\mathrm{Fe}^{2+}$ are important to groundwater chemistry because their inherent toxicity is related to their bioavailability. The result suggests that $\mathrm{Na}^{+}, \mathrm{Ca}^{2+}$, $\mathrm{Mg}^{2+}$ and $\mathrm{K}^{+}$at such level would be available for uptake by plants, animals and humans. It is also highly possible that such conditions may constitute a negative health impact. The model findings also suggest that $\mathrm{Fe}^{2+}$ levels represent a health risks in some water samples.

Acknowledgements :The Authors are grateful to the Authorities of the Federal University of Technology Yola for granting the first author study fellowship to carry out his doctorate degree research work at Abubakar Tafawa Balewa University, Bauchi, Nigeria.The authors are also grateful to the anonymous reviewers for their constructive criticisms that contributed to the success of this paper. Ibrahim 
Ahmed drafted the figures and his tireless effort is gratefully acknowledged.

\section{REFERENCES}

Abdalla, O.A.E (2009) Groundwater recharge/discharge in semi-arid regions interpreted from Isotope and chloride concentrations. Hydrogeology Journal vol (3):679-690

Appelo, C.A and Postma, D (1993) Geochemistry, groundwater and pollution. A.A. Balkema.

Baes, C.F and Mesmer, R.E (1979) The hydrolysis of cations. John Wiley and Sons, New York

Felmy, A.R, Garvin, D.C and Jenne, E.A (1984) MINTEQ A computer program for Calculating aqueous geochemical equilibrium. NTIS PB 84157148(EPA-600/3- 84032) Nat. Tech. Inf. Ser. Springfield

Freeze, R.A and Cherry, J.A (1979) Groundwater Prentice-Hall, Englewood Cliffs, New Jersey
Jenne, E.A (1979) Chemical modeling-goals, problems, approaches and priorities. American Chemical. Society. 3-12

Millero, J (2001) Speciation of metals in natural waters geochemical transactions, 8 .

Obiefuna, G.I (in Preparation) Hydrogeochemistry and groundwater quality of Yola Area, Northeast, Nigeria Unpublished PhD Thesis Abubakar Tafawa Balewa University, Bauchi, Nigeria.

Parkhurst, D.L and Appelo, C. A .J (1999) User's guide to PHREEQC (version 2) - A Computer program for speciation, batch-reaction, onedimensional transport, and inverse geochemical calculations. Water Resources Investigation Report 99-4259, Denver, USA

Tawfic, T.A; Blaylock, M.J and Vance, G.F (1997) Selenite adsorption and solution Complexes in reclaimed mine soils: A comparative study using geochemical models International conference on: Water management, salinity and pollution control Towards sustainable irrigation in the Mediterranean region, Bari Italy. 